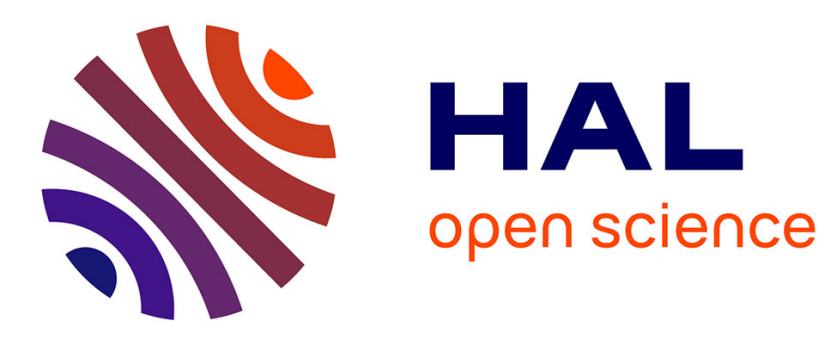

\title{
Shift in plant-soil interactions along a lakeshore hydrological gradient
}

Wenjuan Feng, Mathieu Santonja, Luca Bragazza, Alexandre Buttler

\section{To cite this version:}

Wenjuan Feng, Mathieu Santonja, Luca Bragazza, Alexandre Buttler. Shift in plant-soil interactions along a lakeshore hydrological gradient. Science of the Total Environment, 2020, 742, pp.140254. 10.1016/j.scitotenv.2020.140254 . hal-02892088

\section{HAL Id: hal-02892088 https://hal-amu.archives-ouvertes.fr/hal-02892088}

Submitted on 17 Sep 2020

HAL is a multi-disciplinary open access archive for the deposit and dissemination of scientific research documents, whether they are published or not. The documents may come from teaching and research institutions in France or abroad, or from public or private research centers.
L'archive ouverte pluridisciplinaire HAL, est destinée au dépôt et à la diffusion de documents scientifiques de niveau recherche, publiés ou non, émanant des établissements d'enseignement et de recherche français ou étrangers, des laboratoires publics ou privés. 
1 Title: Shift in plant-soil interactions along a lakeshore hydrological gradient

2

3 Authors: Wenjuan Feng ${ }^{1,2,3,4}$, Mathieu Santonja ${ }^{3,4,5 q^{*}}$, Luca Bragazza ${ }^{3,4,6}$, Alexandre $4 \quad$ Buttler $^{3,4,7}$

5 I $=$ equal contribution to the work

$7 \quad$ Addresses

8 1. Key Laboratory of Watershed Geographic Sciences, Nanjing Institute of Geography and 9 Limnology, Chinese Academy of Sciences, Nanjing, 210008, China

10 2. University of Chinese Academy of Sciences, Beijing, 100049, China

11 3. Ecole Polytechnique Fédérale de Lausanne (EPFL), School of Architecture, Civil and 12 Environmental Engineering (ENAC), Laboratory of Ecological Systems (ECOS), Station 2, 131015 Lausanne, Switzerland

14 4. Swiss Federal Institute for Forest, Snow and Landscape Research (WSL), Site Lausanne, 15 Case postale 96, 1015 Lausanne, Switzerland

16 5. Aix Marseille Univ, Avignon Université, CNRS, IRD, IMBE, Marseille, France

17 6. Agroscope, Field-Crop Systems and Plant Nutrition, Research Division Plant Production 18 Systems, Route de Duillier 50, P.O. Box 1012, CH-1260 Nyon, Switzerland

19 7. Laboratoire de Chrono-Environnement, UMR CNRS 6249, UFR des Sciences et Techniques, 2016 route de Gray, Université de Franche-Comté, F-25030 Besançon, France

$*=$ corresponding author

23 Mathieu Santonja (mathieu.santonja@gmail.com); ORCID: 0000-0002-6322-6352 


\section{Abstract}

Wetlands occupy the transitional zone between aquatic and terrestrial systems. Hydrological conditions have significant influence on wetland plant communities and soil biogeochemistry. However, our knowledge about plant-soil interactions in wetlands along hydrological gradients is still limited, although it is crucial to guide wetland management decisions and to adapt, whenever possible, hydrological conditions to the different plant communities. To this aim, we related vegetation composition, plant functional traits, soil physicochemical properties, soil microbial biomass, and soil enzymatic activities in wetlands on the southeastern shore of Neuchâtel lake, Switzerland, a lake whose level is partly regulated. Aboveground and belowground plant biomass and correspondent $\mathrm{C}, \mathrm{N}$ and $\mathrm{P}$ concentrations remained constant or decreased moving from the vegetation community subjected to more frequent flooding events to the community with almost no flooding. The soil organic layer exhibited always higher nutrient concentrations and greater enzymatic activities than the organo-mineral and mineral layers. The chemical and biological characteristics of the soil organic layer showed decreasing values for most of the parameters along the hydrological gradient from lakeshore to upland wetland communities. On the basis of nutrient stoichiometry, plant-soil system in the plant community with most flooding events had no-nutrient limitation, while there was a $\mathrm{N}$ limitation in the transitional community. In the upland plant community where there was no flooding effect, the plant-soil system was characterized by $\mathrm{N}$ and $\mathrm{P}$ colimitation. These findings are important because they provide a threshold for flooding regime by the lake in the context of optimization of lake level regulation under various stakeholders needs.

Keywords: wetland; flooding; plant biomass; biogeochemistry; nutrient stoichiometry 


\section{Introduction}

Wetlands are important ecosystems supporting biodiversity by providing habitats for numerous plants and animals (Neckles et al., 1990; Gibbs, 2000). Furthermore, they ensure several key ecosystem services such as flood control, groundwater replenishment, water purification, carbon (C) sequestration and they provide livelihoods for local populations (Ramsar, 2013). Extreme climate events such as flooding and drought, as well as anthropogenic activities such as sand mining and agriculture intensification (Lai et al., 2014; Xu et al., 2019) are likely to change the hydrological conditions of wetlands (Hingray et al., 2007; Sarneel et al., 2019) and their habitats (Dawson et al., 2003). In particular, variation in frequency and duration of soil flooding and dryness can profoundly affect biogeochemical cycles of $\mathrm{C}$, nitrogen $(\mathrm{N})$ and phosphorous $(\mathrm{P})$ with cascading effects on wetland plant community composition (Baldwin and Mitchell, 2000; Wang et al., 2015b; Swanson et al., 2017).

Flooding regime affects soil organic $\mathrm{C}$ and nutrient content and availability by controlling microbial mineralization (Wolf et al., 2013; Wang et al., 2015a; Swanson et al., 2017). Accumulation of degraded organic compounds in water saturated soils and under oxygen deficiency (Hopkinson, 1992; Swanson et al., 2017) leads to increasing dissolved soil organic carbon (DOC) and nutrients, resulting partly from $\mathrm{C}, \mathrm{N}$ and $\mathrm{P}$ leaching from leaf litter under rewetting conditions (Baldwin and Mitchell, 2000; Shrestha et al., 2014). Extracellular degrading enzymes are produced by microorganisms in response to environmental signals or through cell lysis (Sinsabaugh et al., 2009; Cui et al., 2018). It has been proved that their higher activities in wet conditions can accelerate organic $\mathrm{C}, \mathrm{N}$ and $\mathrm{P}$ mineralization rates by breaking down large organic molecules for microbial consumption (Wilson et al., 2011; Heuck et al., 2015). Soil organic carbon (SOC) and nutrient concentrations were shown to be relatively higher in the wetter as compared to the drier part in both river and lake wetlands (Bai et al., 2005; Wang et al., 2016) and this increase of nutrient pool promoted microbial activity and 
nutrient cycling (Baldwin and Mitchell, 2000; Heuck et al., 2015). Thus, microbial biomass is both a source and a sink for nutrients and participates to nutrient transformation (Gil-Sotres et al., 2005). However, drying of formerly inundated wetlands may cause a severe C limitation and consequently a decrease in the rate of nutrient cycling because of $\mathrm{C}$ being lost (Baldwin and Mitchell, 2000) and microbial die-off (Qiu and McComb, 1995).

Hydrological conditions in wetlands can have strong impact on plant-soil interactions (Fu et al., 2018; Wang et al., 2018) through changing both organic matter accumulation and mineralization processes (Wilson et al., 2011; Swanson et al., 2017). Plant C, N, P concentrations and their stoichiometric ratios may reflect nutrient availability from substrate and plant nutrient uptake (Demars and Edwards, 2007; Agren, 2008; Elser et al., 2010), Furthermore, the above- and belowground nutrient content and stoichiometry are tightly linked (Bell et al., 2014) and therefore represent important indicators of ecosystem structure and nutrient cycling (Zechmeister-Boltenstern et al., 2015; Sardans et al., 2017). Plant nutrient content and stoichiometry have been studied to detect tissue nutrient allocation (Wang et al., 2015b; Hu et al., 2018), seasonal nutrient variation (Fu et al., 2018), nutrient limitation (Bedford et al., 1999; Demars and Edwards, 2007) or variation between plant functional types (Wang and Moore, 2014; Hu et al., 2018). For example, Li et al. (2017) and Li et al. (2018b) showed that soil nutrient content and stoichiometry are changing along hydrological gradients, and that plant nutrient content and stoichiometry are regulated rather by flooding duration than by soil nutrient content.

Different plant species and their abundances can also cause variation in soil and microbial nutrient stoichiometry (De Graaff et al., 2010; Bell et al., 2014) and modulate ecosystem functions through ecological processes affecting microbial and enzymatic activities (Bever et al., 2010; Kardol et al., 2010). There are ample evidences of the close relationships among plant species and soil stoichiometry (Hobbie et al., 2006; Bell et al., 2014; Wang et al., 2018). Pattern 
of nutrient availability varies among plant species (Bedford et al., 1999; Güsewell and

101 Koerselman, 2002) and conversely, plants apply some control over nutrient availability by

102

103

104 driving soil microbial and enzymatic activities (Richardson et al., 2009; Sardans and Peñuelas, 2012; Bragazza et al., 2015). Along hydrological gradients, the relationship between plant functional traits and soil properties has been explored in wetlands, revealing potential plant-soil relationships (Liu et al., 2015; Wang et al., 2015b; Hu et al., 2018).

In the present study, we investigated soil physico-chemical characteristics (including $\mathrm{C}$, $\mathrm{N}, \mathrm{P}$ stock and availability), soil microbial biomass nutrients $(\mathrm{C}, \mathrm{N}, \mathrm{P})$, soil enzymatic activities, and nutrient content in plant and moss biomass $(\mathrm{C}, \mathrm{N}, \mathrm{P})$ in three plant communities along a hydrological gradient from lakeshore to upland. Investigations took place at the beginning and at peak of the growing season in a wetland along the southern shore of Lake Neuchâtel, Switzerland. We hypothesized that: (i) soil nutrient content, microbial biomass and enzymatic activities, and plant nutrient content are higher in the flooded areas near the lakeshore as compared to the upland area; (ii) the nutrient stoichiometry of plant and soil components can reveal contrasted ecosystem functioning along the hydrological gradient, with a $\mathrm{N}$ and $\mathrm{P}$ limitation for plant communities of the upland area, as opposed to no $\mathrm{N}$ and $\mathrm{P}$ limitation for the plant communities close to the lakeshore subjected to flooding.

\section{Materials and methods}

\subsection{Study site}

The study was conducted in the wetlands along the southern shore of Lake Neuchâtel $\left(46^{\circ} 54^{\prime} 28^{\prime \prime} \mathrm{N}, 6^{\circ} 52^{\prime} 02^{\prime \prime} \mathrm{E}\right)$ in Switzerland, which is the Ramsar site called "Grande Cariçaie". The climate is defined as pluvial sub-oceanic (Buttler, 1990) with a mean annual temperature of $9.4{ }^{\circ} \mathrm{C}$ and mean annual precipitation of $891 \mathrm{~mm}$ (MeteoSuisse, 
https://www.meteosuisse.admin.ch - Payerne, period 1981-2010). Five main plant communities, respectively dominated by Molinia caerulea (L.) Moench, Schoenus nigricans L., Carex panicea L., Carex elata All. and Phragmites australis (Ca.) Steud. can be found moving from the upland wetland to the lake shoreline (Buttler et al., 1985; Buttler and Gallandat, 1989; Buttler and Muhlhauser, 1994). These plant communities experience an annual flooding regime depending on the lake water level, which is partly regulated and is on average low in winter, high in spring and intermediate in summer and autumn (https://www.hydrodaten.admin.ch/fr/2149.html). Thus, flooding by the intrusion of the lake into the wetland occurs mainly in spring and early summer time, and relates to the snowmelt in the Alps. Heavy rain can recharge the soil water rapidly in autumn, which translates into superficial flooding's event in the upland wetlands which are not influenced by the lake water (Buttler, 1987).

\subsection{Sampling design}

Distinct plant communities distributed along an elevation gradient (i.e. transects from lakeshore to upland) were selected, a method frequently used in wetland ecosystem studies (e.g. Li et al., 2017; Fu et al., 2018). The three plant communities dominated by C. elata, C. panicea and S. nigricans were selected for this study because they represent the interface between the vegetation influenced by the lake intrusion into the wetland, e.g. Caricetum elatae W. Koch 26, variant with Phalaris arundinaceae, the transitional vegetation, e.g. Caricetum elatae W. Koch 26, variant with Carex panicea and the vegetation not reached by the lake, e.g. OrchioSchoenetum nigricantis Oberd. 57, variant with Galium palustre (Buttler and Gallandat, 1989).

Along this gradient, which is topographically characterized by a gentle slope with about 30-60 $\mathrm{cm}$ increase of soil level towards the upland wetland, soils show a marked hydromorphic feature: 
histic humaquept (C. elatae community), wet typic haplaquoll (C. panicea community) and dry typic haplaquoll (S. nigricans community) (Buttler and Gobat, 1991).

Four transects at least $1 \mathrm{~km}$ apart were established from the upland to the shoreline (Supplementary Fig. S1). In each of the three plant communities crossed by these transects, one $10 \mathrm{~m} \times 10 \mathrm{~m}$ plot was randomly selected, leading to a total of 12 plots ( 4 transects $\times 3$ plant communities). The different botanical compositions in different plots are given in the Supplementary Table S1. One piezometer was installed in each plot to monitor the soil water level (Supplementary Fig. S2). Carex elata community was mostly flooded with decreasing water levels during the study period, $C$. panicea community experienced wet conditions with soil saturated in spring and a subsequent drop of water level below $-35 \mathrm{~cm}$ in August, and $S$. nigricans community, typically never flooded with water level decreasing from -4 to $-70 \mathrm{~cm}$ during the measurement period. Data loggers (Onset HOBO Water Temp Pro v2) were also installed in the soil at $5 \mathrm{~cm}$ depth to monitor the soil temperature (Supplementary Fig. S3).

Overall, from March to August, the top-soil temperature increased regularly from $5{ }^{\circ} \mathrm{C}$ to more than $20{ }^{\circ} \mathrm{C}$, with the soil in $C$. elata community being always slightly colder than that in $C$. panicea and $S$. nigricans communities, which had very similar temperatures.

\subsection{Plant and soil collection}

Plant and soil samples were collected in all plots at the beginning of the plant growing season (April 2018) and at the peak of plant biomass (July 2018) (Supplementary Fig. S4). In addition to the groundwater level measured with the piezometers, the soil volumetric water content was measured at $0-10 \mathrm{~cm}$ depth in each plot and at each sampling time using a portable TDR (FieldScout TDR100, UK).

Aboveground vascular plant biomass (AGB), moss biomass (MB) and plant litter (L) were collected in all plots using a $50 \mathrm{~cm} \times 50 \mathrm{~cm}$ quadrat in $S$. nigricans and C. panicea 
communities, and a $100 \mathrm{~cm} \times 100 \mathrm{~cm}$ quadrat in C. elata community. Vascular plants were clipped at the ground level, while litter and mosses were picked up carefully to avoid soil particles. All the aboveground material was placed in separated bags, transported to the laboratory, and then oven-dried at $65^{\circ} \mathrm{C}$ for 4 days. Once oven-dried, this plant material was weighted in order to estimate the dry mass (DM) per square meter for each plot and kept for further analysis.

Three soil cores $(5.6 \mathrm{~cm}$ diameter $\times 30 \mathrm{~cm}$ depth) per plot were randomly collected (inbetween the tussocks for $C$. elata and $S$. nigricans communities) for belowground biomass (BGB - roots and rhizomes) sampling. The same layers as for soil sampling (see below) were used and pooled so as to have a composite sample for each layer. Roots and rhizomes were carefully collected by gentle washing in water. As for the aboveground material, the belowground biomass was oven-dried at $65{ }^{\circ} \mathrm{C}$ during 4 days and weighted in order to estimate the dry mass (DM) per square meter for each plot and kept for further analysis.

Three other soil cores $(5.6 \mathrm{~cm}$ diameter $\times 30 \mathrm{~cm}$ depth) per plot were collected in a similar way for the soil sampling as for the belowground biomass. Based on the soil color and texture, each soil core was divided into three parts: organic layer (OL), organo-mineral layer (OML), and mineral layer (ML) (Supplementary Figs. S4 and S5). The top $5 \mathrm{~cm}$ of the organic layers from the three soil cores were collected and pooled in one composite sample. For the organomineral layer, the $5 \mathrm{~cm}$ immediately below the entire organic layer were taken and pooled. For the mineral layer, the upper $2 \mathrm{~cm}$ of this layer was removed to avoid irregular transition and the following $5 \mathrm{~cm}$ below were collected, which again were pooled in one composite sample. These samples were placed in polyethylene bags, transported to the laboratory and stored at $4{ }^{\circ} \mathrm{C}$ until being further processed.

In order to determine the soil bulk density (BD), a last soil core was sampled and an intact piece $\left(5.6 \mathrm{~cm}\right.$ diameter $\times 5 \mathrm{~cm}$ depth) was taken for each soil layer and oven-dried at $105{ }^{\circ} \mathrm{C}$ 
199

200

201

202

203

204

205

206

207

208

209

210

211

212

213

214

215

216

217

for $48 \mathrm{~h}$ and weighted. Bulk density was calculated by dividing the mass of the oven-dried soil sample by its volume and expressed as $\mathrm{g} . \mathrm{cm}^{-3}$.

\subsection{Plant and moss $C, N$ and $P$ analyses}

A subsample of dry plant material was washed and dried again, then ground to a fine powder using a ball mill before chemical analysis. Total organic carbon (C) and total nitrogen (N) concentrations were determined by thermal combustion using an elemental analyzer (CE Instruments model NA2500 Nitrogen Carbon Analyzer) and expressed as percent of dry weight. Total phosphorus $(\mathrm{P})$ concentration was determined by the molybdenum blue method after $\mathrm{HClO}_{4}-\mathrm{H}_{2} \mathrm{SO}_{4}$ digestion using a continuous flow autoanalyser (FlowSys, Systea, Anagni, Italy) and expressed as percent of dry weight. Finally, C:N, C:P and N:P stoichiometric ratios were calculated for aboveground and belowground plant biomass, plant litter and moss biomass (Supplementary Fig. S4).

\subsection{Soil chemical analyses}

For chemical analyses, any visible coarse plant material in the soil samples was removed by hand-sorting. Soil samples were divided into two subsamples: i) a subsample was oven-dried at $65{ }^{\circ} \mathrm{C}$ for 4 days and ground to a fine powder using a ball mill in order to determine total organic $\mathrm{C}(\mathrm{TOC}), \mathrm{N}(\mathrm{TN})$ and $\mathrm{P}(\mathrm{TP})$ concentrations, and ii) a fresh subsample was stored at 4 ${ }^{\circ} \mathrm{C}$ in order to determine soil $\mathrm{pH}$, nitrate $\left(\mathrm{N}^{-\mathrm{NO}_{3}}{ }^{-}\right)$and ammonium $\left(\mathrm{N}-\mathrm{NH}_{4}{ }^{+}\right)$concentrations, dissolved organic C (DOC), N (DN) and P (DP) concentrations, soil microbial biomass and soil enzymatic activities. For the determination of soil water content (SWC) and in order to quantify all the measured parameters per $\mathrm{g}$ of dry soil weight, $10 \mathrm{~g}$ of fresh soil samples for each replicate were oven-dried at $105^{\circ} \mathrm{C}$ for $48 \mathrm{~h}$. In addition, these oven-dried samples were burned at $550{ }^{\circ} \mathrm{C}$ for $6 \mathrm{~h}$ in order to determine the soil organic matter content by loss of ignition (LOI). 
TOC, TN and TP were determined for each replicate following the same methods as for

225 plant and moss material and expressed as percent of dry soil weight. Soil $\mathrm{pH}$ was measured in 1:5 (w/v) soil water suspension with a portable $\mathrm{pH}$ meter (WTW multi 3430, Weilheim,

227 Germany) after stirring the mixture for $2 \mathrm{~h} . \mathrm{N}_{-} \mathrm{NH}_{4}{ }^{+}$and $\mathrm{N}^{-\mathrm{NO}_{3}}{ }^{-}$concentrations were 228 determined after extraction of $5 \mathrm{~g}$ of fresh soil with $30 \mathrm{ml}$ of $1 \mathrm{M} \mathrm{KCl}$ extraction and filtration 229 through $0.45 \mu \mathrm{m}$ filter using a continuous flow autoanalyzer (SEAL Analytical, Germany) and 230 the results were expressed as $\mathrm{mg} \cdot \mathrm{kg}^{-1}$ oven dry soil.

Microbial biomass carbon (MBC), nitrogen (MBN) and phosphorus (MBP) were measured using the chloroform fumigation extraction method (Brookes et al., 1985). Three pairs of about $5 \mathrm{~g}$ of fresh soil ( $3 \mathrm{~g}$ for MBP) were weighed for each replicate. One sample from 234 each pair was stored at $4{ }^{\circ} \mathrm{C}$ while the other sample was put in a vacuum desiccator and 235 subjected to chloroform vapor. After $24 \mathrm{~h}$ of fumigation in the dark at ambient temperature, the 236 fumigated soil samples and the corresponding ones kept unfumigated in the fridge were extracted with a $25 \mathrm{ml}$ of $0.5 \mathrm{M} \mathrm{K}_{2} \mathrm{SO}_{4}$ for $\mathrm{MBC}$ and $\mathrm{MBN}$ and with $40 \mathrm{ml}$ of $0.5 \mathrm{M} \mathrm{NaHCO}_{3}$ for MBP. All solutions were filtered through a $0.45 \mu \mathrm{m}$ filter before analysis. Organic $\mathrm{C}$ and $\mathrm{N}$ 239 concentrations in the solutions from both fumigated and unfumigated samples were determined using a TOC/TN analyzer (Shimadzu TOC-V), while P concentration was determined by colorimetry using a spectrophotometer at $890 \mathrm{~nm}$ (Olsen et al., 1954). Soil DOC, DN and DP were determined as the concentrations obtained from the unfumigated samples. The soil MBC,

$243 \mathrm{MBN}$ and MBP values were estimated as the differences between fumigated and unfumigated 244 samples using an extractability factor of 0.45 for C (Vance et al., 1987), 0.54 for $\mathrm{N}$ (Brookes et 245 al., 1985) and 0.40 for P (Brookes et al., 1982) and expressed as mg.kg-1 oven dry soil. In order to measure the soil enzymatic activities, $1 \mathrm{~g}$ of fresh soil was mixed with $10 \mathrm{ml}$ 247 of water, stirred for $1 \mathrm{~h}$, and the supernatant was collected after centrifugation. The activities 248 of extracellular hydrolase enzymes were measured by adding $50 \mu 1$ of 4-methylumbelliferyl- $\beta$ - 
D-glucoside for the activity of $\beta$-glucosidase (BG), 4-MUF-N-acetyl- $\beta$-D-glucosaminide for

250 the activity of $\mathrm{B}-1,4-\mathrm{N}$-acetylglucosaminidase (NAG), L-leucine-7-amido-4-methycoumarin 251 hydrochloride for the activity of leucine aminopeptidase (LAP) and 4-MUF-phosphate for the 252 activity of phosphatase (PHO) to $250 \mu \mathrm{l}$ of the soil extract. After $2 \mathrm{~h}$ of incubation, the 253 fluorescence was measured on a microplate reader (BioTek SynergyMX) at $450 \mathrm{~nm}$ emission 254 and $330 \mathrm{~nm}$ excitation wavelength. To quantify product release and account for quenching 255 effects, a set of standards was prepared using methylumbelliferone (MUF) and 7-amino-4256 methylcoumarin (MUC) mixed with soil extract. Enzymatic activities were expressed as $\mu \mathrm{mol}$ 257 of substrate (MUF and MUC) converted per min and per g (dry weight) of soil (Freeman et al., 258 2004).

The C:N, C:P and N:P stoichiometric ratios were calculated for bulk soil and its dissolved 260 fraction and for microbial biomass.

\subsection{Data analysis}

Statistical analyses were performed with the R software 3.2.3 (R. Core Team, 2017). When necessary, data were log or square root transformed, and the normality and homoscedasticity of the distribution of residuals of models were visually verified.

We used a linear mixed effects model approach (“nlme'” package, Pinheiro et al., 2020), followed by Tukey HSD tests for post hoc comparisons, to test the effects of vegetation type (C. elata, C. panicea or S. nigricans community), growing season (beginning or peak of the growing season), and their interactions on plant and moss parameters. To consider the fact that 270 we had three plots per transect, the random part of the model indicated that the plots were nested 271 within transects. For what concerns the soil physico-chemical, microbial and enzymatic parameters, we 273 used a linear mixed-effects model approach followed by Tukey HSD tests for post hoc 
comparisons in order to test the effects of soil layers (organic, organo-mineral or mineral layer), vegetation type (C. elata, C. panicea or S. nigricans community), growing season (beginning or peak of the growing season), and their interactions, specifying soil layers nested into plots nested into transects as random factor.

A redundancy analysis (RDA) was used to link the plant chemical characteristics of the three vegetation types taken at two sampling times $(\mathrm{C}, \mathrm{N}$ and $\mathrm{P}$ contents and their stoichiometry in above- and belowground plant biomass, moss biomass and plant litter) as a response to the soil characteristics (chemical and biological variables - see Supplementary Tables S2 and S3). Finally, a principal component analysis (PCA) was used to determine the correlations between stoichiometry of $\mathrm{C}, \mathrm{N}$ and $\mathrm{P}$ in the plant material, in the bulk soil and in its dissolved fraction, and in the microbial biomass.

\section{Results}

\subsection{Plant and moss parameters}

Litter mass and belowground biomass were between 2.4 and 3.5 times higher in C. elata community compared to $C$. panicea and $S$. nigricans communities (Table 1 and 2; Supplementary Table S2), while differences in aboveground and moss biomass among the three plant communities were dependent on the sampling time during the growing season (significant vegetation type $\times$ growing season interaction, Table 1 ). At the beginning of the growing season, aboveground biomass of $C$. elata community was lower than that of $C$. panicea and S. nigricans communities, while aboveground biomass of $C$. elata community was higher than that of $C$. panicea at the peak of growing season (Fig. 1a). Concerning moss biomass, there was no difference among plant communities at the beginning of growing season, while moss biomass of $C$. elata community was 5 times higher than that of the two other plant communities at the 
peak of growing season (Fig. 1b). When summing all plant and moss materials, the organic matter stock was approximately 2.5-time higher in C. elata community (10'063 g.m ${ }^{-2}$ ) as compared to C. panicea (4'037 g.m $\left.\mathrm{m}^{-2}\right)$ and $S$. nigricans $\left(3^{\prime} 803 \mathrm{~g} \cdot \mathrm{m}^{-2}\right)$ communities. The aboveground biomass increased more than 8 times during the growing season, while litter mass was 30\% lower (Table 2; Supplementary Table S2). Belowground biomass decreased by 32\% from the beginning to the peak of biomass period, while moss biomass increased 1.6-times, although these trends were not significant (Tables 1 and 2; Supplementary Table S2).

Carbon content in belowground biomass and litter were higher in C. elata community compared to S. nigricans community (Table 1; Supplementary Table S2). Nitrogen content in aboveground biomass of $C$. panicea community was similar to that of the $C$. elata community and higher than that of $S$. nigricans community at the beginning of the growing season, while it was similar to that of $S$. nigricans community and lower than that of $C$. elata community at the peak of the growing season (significant vegetation type $\times$ growing season interaction, Table 1; Fig. 1c). Phosphorus content in aboveground biomass showed a trend of decrease according to the gradient $C$. elata $>C$. panicea $>$ S. nigricans, i.e. from lakeshore to upland communities (Table 1; Supplementary Table S2). The decrease in P content in aboveground biomass during the growing season was dependent on the plant community (significant vegetation type $x$ growing season interaction, Table 1), since the P content decreased only in the C. elata and C. panicea communities (Fig. 1d).

Nitrogen and $\mathrm{P}$ content in moss biomass was also higher in $C$. elata compared to $S$. nigricans community (Table 1; Supplementary Table S2). In litter, C content increased, while $\mathrm{N}$ content decreased during the growing season, and in belowground biomass both $\mathrm{N}$ and $\mathrm{P}$ contents decreased during the growing season (Tables 1 and 2; Supplementary Table S2).

\subsection{Soil physico-chemical parameters}


Bulk density and $\mathrm{pH}$ increased according to the gradient organic > organo-mineral > mineral layers (i.e. soil depth) while, in the opposite, all other physico-chemical parameters decreased according to soil depth (Tables 3 and 4; Supplementary Table S3). Moreover, bulk density and $\mathrm{pH}$ increased from lakeshore to upland plant communities while, in the opposite, all other physico-chemical parameters decreased according to this vegetation gradient (Tables 3 and 4; Supplementary Table S3). Overall, more physico-chemical parameters were significantly different between $C$. elata and $C$. panicea communities than between $C$. panicea and S. nigricans communities (Supplementary Table S3).

Except for soil $\mathrm{pH}$ and nitrate, the differences among the three plant communities were dependent on the soil layer (significant soil layer $\times$ vegetation type interaction, Table 3 ), with decreasing differences among plant communities according to increasing soil depth. For example, while we observed marked differences for soil total P (TP) and available P (DP) in organic layer among plant communities, the values of mineral layer were much less marked or similar between plant communities (Fig. 2a and b). The differences in soil available C (DOC) and nitrate contents among the 3 plant communities were also dependent on the growing season (significant vegetation type $\times$ growing season interaction, Table 3 ). Soil DOC values were similar between the 3 plant communities at the beginning of the growing season, while DOC was higher in $C$. elata compared to the two other communities at the peak of growing season (Fig. 3a). Soil nitrate was higher in $C$. elata and $C$. panicea communities compared to $S$. nigricans community at the beginning of the growing season, while similar values between the three plant communities were observed at the peak of growing season (Fig. 3b).

Only few soil physico-chemical parameters varied across the growing season (Table 3). Soil $\mathrm{pH}$ and $\mathrm{DN}$ increased while, on the opposite, nitrate decreased between the beginning and the peak of the growing season (Tables 3 and 4; Supplementary Table S3). The increase in soil available $\mathrm{N}(\mathrm{DN})$ across the growing season was higher in the organic and organo-mineral 
layers compared to the mineral layer (significant soil layer $\times$ growing season interaction, Table

3503 ; Fig. 4a), while ammonium content increased only in the organic layer (significant soil layer $351 \times$ growing season interaction, Table 3; Fig. 4b).

\subsection{Soil microbial biomass and enzyme activity}

Soil microbial biomass and enzymatic parameters decreased according to soil depth and according to the vegetation gradient from lakeshore to upland (Tables 3 and 4; Supplementary Table S3). Contrary to microbial biomass, the four enzymatic activities varied across the growing season (Table 3), with higher values reported at the peak compared to the beginning of growing season (Table 4; Supplementary Table S3).

Except for leucine aminopeptidase activity, the differences in microbial biomass and enzymatic parameters among the three plant communities were dependent on the soil layer considered (significant soil layer $\times$ vegetation type interaction, Table 3 ), with decreasing differences according to increasing soil depth (Fig. 2c and d). Finally, the differences in enzymatic parameters among plant communities or among soil layers were stronger at the peak compared to the beginning of growing season (significant soil layers $\times$ growing season and vegetation type $\times$ growing season interactions, Table 3 ).

\subsection{Plant-soil interactions}

The redundancy analysis model (RDA) provides a synthetic view on the relationship

369 between plant chemical characteristics as a response to soil characteristics in the upper organic 370 layer at two sampling periods, April and July (Supplementary Fig. S6). C. elata community 371 samples are strongly linked, along axis 1, to high values of $\mathrm{N}$ and $\mathrm{P}$ in aboveground biomass, 372 moss biomass and plant litter, while belowground biomass samples vary mostly along axis 2, 373 with higher $\mathrm{P}$ and $\mathrm{N}$ values in April. 
The relationships among stoichiometry of $\mathrm{C}, \mathrm{N}$ and $\mathrm{P}$ in all sampled compartments (plant, 375 moss, soil and microbial biomass) in April and July are given in the principal component analysis (PCA) of the Fig. 5. C. elata community samples are mostly positively correlated to soil dissolved $\mathrm{C}: \mathrm{N}$ ratio and strongly negatively correlated to $\mathrm{C}: \mathrm{P}$ and $\mathrm{N}: \mathrm{P}$ in microbial biomass. Samples of $C$. panicea community are mostly positively correlated to $\mathrm{C}: \mathrm{N}$ ratios in belowground biomass, in bulk soil and also weakly in microbial biomass, and strongly negatively correlated to $\mathrm{C}: \mathrm{P}$ and $\mathrm{N}: \mathrm{P}$ ratios in bulk soil and in belowground biomass, as well as in soil dissolved C:P. Finally, samples of $S$. nigricans community are positively correlated to several ratios, in particular to $\mathrm{C}: \mathrm{P}$ and $\mathrm{N}: \mathrm{P}$ ratios in microbial biomass, to soil dissolved $\mathrm{N}: \mathrm{P}$, to bulk soil $\mathrm{C}: \mathrm{N}$ ratio and to $\mathrm{C}: \mathrm{N}, \mathrm{C}: \mathrm{P}$ and $\mathrm{N}: \mathrm{P}$ ratios in aboveground biomass, moss and litter.

\section{Discussion}

\subsection{Plant biomass and its nutrients content reflect the hydrological gradient induced by the} lake flooding

The seasonal pattern of aboveground biomass was different among the three vegetation types. In spring, before the vegetation started to grow, $C$. elata had the lowest aboveground biomass, but later in the season, at the peak of biomass period, the trend reversed and C. elata community developed more biomass compared to $C$. panicea and S. nigricans communities (in this later case the difference was only marginal). This reflects in the litter accumulation, which was higher in $C$. elata community. Mosses also developed more during the vegetation period in C. elata community due to the very favorable microclimatic conditions resulting from high soil moisture and shading conditions under the tussocks. The total plant biomass reflects well the hydrological gradient, with highest values in C. elata community and lowest in S. nigricans community. Li et al. (2017) found opposite results for biomass distribution along an elevation 
gradient in Dongting Lake wetland (China), with increasing aboveground biomass with decreasing soil water content. This can be explained by the different hydrological conditions in these two wetlands. In Dongting Lake wetland, the upland plant community still experiences an annual flooding event, similarly to the community close to the lake shoreline and therefore its ecological functioning cannot be assimilated to a conservative nutrient poor biogeochemical cycle as in the $S$. nigricans community investigated in the present study.

As we hypothesized, plant nutrient content generally decreased along the hydrological gradient, with higher values in $C$. elata community, which is under the influence of the lake flooding. This was particularly true for $\mathrm{N}$ and $\mathrm{P}$ content in plant aboveground and moss biomasses. The concentrations of these two elements in aboveground biomass also showed the intermediate status of $C$. panicea community, as exemplified by its $\mathrm{N}$ content which was similar to $C$. elata in spring, when both vegetation types were flooded by the lake, and similar to $S$. nigricans later in the dryer season (Fig. 1c). Nutrients provided by the lake water are important sources for wetland plants, and indeed, in C. elata community, and to some extend also in $C$. panicea community, vascular plants and mosses could absorb more nutrients than in $S$. nigricans community, which contributed to the higher biomass accumulation. Furthermore, $\mathrm{C}$ and nutrients from the litter leachates (Demars and Edwards, 2007; Shrestha et al., 2014) and organic matter accumulation (Wilson et al., 2011; Swanson et al., 2017) under flooding conditions are also beneficial for the plant nutrient absorption and growth.

We assessed the nutrient content in aboveground and moss biomass by pooling the plant species, since each plant community was dominated by only a few species (Buttler, 1987, see also Supplementary Table S1). Nevertheless, plant nutrients can show a high interspecific variability and low phenotypic response to nutrient supply (Demars and Edwards, 2007; Li et al., 2017; Hu et al., 2018). Plants have lower nutrient resorption proficiency in nutrient-rich environment (Hopkinson, 1992; Mao et al., 2016), while under extremely low nutrient 
availability, they can adapt by maintaining small nutrient concentrations in photosynthetically active tissues (Wang and Moore, 2014). In S. nigricans community, we can speculate that plants could transfer and store more nutrients into the living roots. It was also observed that shoots remain partly green over winter, which can contribute to the storage of nutrients, while all the aboveground biomass dies out in C. elata vegetation (personal observations). As a consequence, in S. nigricans community these nutrients could be mobilized during the growing season and allow for relatively high aboveground biomass production as compared to C. elata community (Fig. 1a, no statistical difference between $\mathrm{CE}$ and $\mathrm{SN}$ at the peak of biomass). Nutrient translocation was the reason why litter quality was increased with nutrient enrichment in Nlimited wetlands (Mao et al., 2016). We did not detect any vegetation type $\times$ growing season cross effect for accumulated litter and its quality (Table 1), so that we assume that the existing litter became similar in the different vegetation types during winter decomposition already. Litter decomposition was mostly related to leaf $\mathrm{N}$ content (de Neiff et al., 2006) and flooding can accelerate decomposition through increasing soil moisture (Shrestha et al., 2014; Heuck et al., 2015) and nutrient leaching (Baldwin and Mitchell, 2000; Shrestha et al., 2014). This could explain why, despite initial nutrient concentration differences in early senescent biomass and distinct nutrient translocation capacity in the three communities, there was no significant differences in litter $\mathrm{N}$ and $\mathrm{P}$ contents. However, $\mathrm{C}$ content in litter decreased along the hydrological gradient, with highest values in C. elata and lowest in S. nigricans communities. This difference of litter $\mathrm{C}$ content potentially provides more energy for microorganisms in the C. elata community.

From a stoichiometric perspective, in aboveground and moss biomass, C:N, C:P and N:P ratios were significantly lower in $C$. elata and higher in $S$. nigricans communities (Supplementary Table S4). Even if this trend is still visible in the litter, differences were nonsignificant, which could advocate for similar decomposition rates. In litter bags decomposition 
experiments, Buttler (1987) found that $k$ decomposition rates were $0.229,0.224$ and 0.253 for

450 C. elata, C. panicea and S. nigricans communities, respectively, thus a higher decomposability

451 for the litter in S. nigricans community was measured. This discrepancy can be explained by

452 the quality of the litter used. Because of the plant morphology, fresh litter can easily be collected

453 on S. nigricans tussocks at the end of the growing season as standing senescent leaves, while

454 for Carex species, these senescent leaves tend to fall down and mix with older leaves on the

455 ground, so that litter samples might be more heterogeneous and comprise leaves in a more 456 advanced decomposition stage.

457

\subsection{Soil organic matter quantity and quality reflects the flooding regimes}

Under intensive flooding, as happened in C. elata community near the lakeshore, there was more than double the amount of organic matter accumulated in the ecosystem, as compared to $C$. panicea and S. nigricans communities. With respect to the belowground biomass, which was also highest in C. elata community, it cannot be concluded on higher root growth as it was not possible to distinguish between living and dead roots, but lower soil bulk density can

464 indicate higher organic matter content in relation to higher root productivity (Rokosch et al.,

465 2009). As for litter, the strong decrease of belowground biomass during the growing season 466 points to the degradation of dead organic matter. In the belowground biomass, there was no 467 difference in plant $\mathrm{N}$ and $\mathrm{P}$ concentrations among the three communities, despite different soil 468 nutrient conditions (Table 4). Like for the N:P ratio of above-ground biomass and mosses, the $469 \mathrm{~N}: \mathrm{P}$ ratio of belowground biomass was higher in the $S$. nigricans community where there is no 470 flooding than in the other two communities. This result is contrary to the finding in Wang et al. 471 (2018) where N:P ratio of belowground biomass was increased with flooding intensity. These 472 opposed results might be explained by distinct nutrient limitation in the two study areas. Below473 ground biomass $\mathrm{C}$ content decreased along the hydrological gradient, with highest values in $C$. 
elata and lowest in S. nigricans communities, which mirrors in the trend for higher belowground biomass $\mathrm{C}: \mathrm{N}$ and $\mathrm{C}: \mathrm{P}$ ratios in $C$. elata community. This reflected the humus types, which were marked differently by hydromorphic features: peaty anmoor, anmoor-hydromull and hydromull in C. elata, C. panicea and S. nigricans communities, respectively (Buttler and Gobat, 1991). This is consistent with the decrease of soil organic matter and C contents along the vegetation gradient, as well as in the increase of bulk density and $\mathrm{pH}$ (Table 4 and Supplementary Table S3).

\subsection{High organic matter in wetter soils triggers enzyme activity, which in turn accelerates}

\section{nutrient mineralization}

The soils in the three plant communities differed in their chemical and biological characteristics of their surface organic layer, which showed, as hypothesized, decreasing values for most of the parameters along the hydrological gradient, from C. elata to S. nigricans communities. Thus, higher soil fertility near the lakeshore also allowed higher microbial biomass. Along the growing season, DOC increased markedly in C. elata community, as a result of intense organic matter decomposition of the accumulated litter under high soil biological activity. Thus, higher organic matter contributed to the enzyme activity, which in turn could accelerate nutrient mineralization (Wilson et al., 2011; Heuck et al., 2015). Conversely, nitrate was higher at the beginning of the vegetation period, but decreased thereafter because it was used readily for the high biomass production, and consequently the soils could not be differentiated anymore by their nitrate content at the peak of biomass. Enzyme activity was affected not only by the availability of organic matter, but was also promoted by temperature increase during the growing season (Sinsabaugh et al., 2008; Manzoni 


\subsection{Plant-soil interaction and nutrient limitation in different hydrological conditions}

The three studied vegetation types are characterized by different nutrient requirements and, according to our hypothesis, this translates into different nutrient limitation and stoichiometric ratios in the plant material, soil and microbial pools. In C. elata community, $\mathrm{N}$ and $\mathrm{P}$ are not limiting because of the regular input of nutrients by lake water. With respect to $\mathrm{NO}_{3}$, values were on a yearly average $1.7 \mathrm{mg} . \mathrm{L}^{-1}$ in the lake water, as opposed to $0.1 \mathrm{mg} . \mathrm{L}^{-1}$ in the soil solution of the organic layer in the considered soils, while values for $\mathrm{PO}_{4}$ were indifferently $0.1 \mathrm{mg} . \mathrm{L}^{-1}$ in both the lake water and the upper horizon of these soils, but undetectable in the deeper horizons (Buttler, 1992). This shows that despite the inflow of nutrients from the lake in the wettest plant communities, the nutrient content in the soil does not discriminate the plant communities, despite obvious differences in biomass production and associated nutrient content (this study and Buttler, 1992). This is explained by the immediate uptake of nutrients for biomass production and its feedback effect onto the soil during the vegetation period in wetlands (Dykyjová and Úlehlová, 1978; Bayley et al., 1985). Indeed, hydrological differences among the various vegetation communities can affect soil organic matter accumulation and mineralization processes (Wilson et al., 2011; Swanson et al., 2017), as well as plant nutrient resorption (Wang et al., 2015a). Finally, losses of nutrients from soil organic matter and litter decomposition are important for the eutrophic vegetation influenced by the lake and contribute to a high $\mathrm{C}: \mathrm{N}$ ratio in the soil dissolved fraction. It has been reported that dissolved organic carbon was higher under flooding than non-flooding condition in floodplain vegetation (Shrestha et al., 2014) and it was increased by flooding duration (Blodau and Moore, 2003; Kim et al., 2014). Therefore, for vegetation under the influence of lake inundation and high nutrient inputs, there is a rapid turnover of nutrients. Conversely, in the upland wetland vegetation characterized by S. nigicans, which is never affected by lake flooding, $\mathrm{N}$ and $\mathrm{P}$ are limiting, which translates in high $\mathrm{N}: \mathrm{P}$ ratios in the soil dissolved fraction 
as well as high $\mathrm{C}: \mathrm{N}, \mathrm{C}: \mathrm{P}$ and $\mathrm{N}: \mathrm{P}$ ratios in aboveground biomass, mosses and litter, as well as

525 high $\mathrm{C}: \mathrm{P}$ and $\mathrm{N}: \mathrm{P}$ ratios in the microbial biomass. Under such low nutrient availability, nutrient translocation from senescing tissues is a strategy for plants to retard nutrient loss (Hopkinson,

527 1992; Aldous, 2002). This translocation process of nutrients to roots by species such as $S$. nigricans (also Molinia caerulea and M. arundinacea, both present in S. nigricans community) is specific to a conservative biogeochemical cycle. In $C$. panicea community, which has an intermediate position along the vegetation gradient, only $\mathrm{N}$ is limiting, which translates into high $\mathrm{C}: \mathrm{N}$ ratios in bulk soil, below-ground biomass and microbial biomass, and low $\mathrm{C}: \mathrm{P}$ and $\mathrm{N}: \mathrm{P}$ ratios in bulk soil and below-ground biomass, as well as low $\mathrm{C}: \mathrm{P}$ ratio in the soil dissolved fraction.

\section{Conclusion}

High nutrient concentrations in plant leaves tend to be associated with the "live-fast/die young" end of the leaf economics spectrum (Wright et al., 2004; Kazakou et al., 2007), a characteristic which holds for the lakeshore vegetation under the influence of the lake flooding, as opposed to the upland wetland vegetation, which is never reached by lake flooding (Bueche et al., 1994). Our findings have strong implication for wetland management. The wetland hydrodynamic depends strongly on the lake level regulation at the outlet of the lake Neuchâtel, where a dam has been built (Buttler et al., 1995). It is a request to the hydraulic managers to consider the various stakeholders needs for setting the water level curve along the year. Constraints are given by the electricity power plants on the Aar river, navigation on the Rhin river, agriculture in the floodplains around the lake, fisheries and nature conservancy on the south shore of lake Neuchâtel which has become a Ramsar site. In this respect, the wetland vegetation and their soils are sensitive to lake flooding regime, as it was shown in this study. It is therefore important that the water level of the lake is set to optimize the flooding regime in 
549 the wetland, more specifically that most of the vegetation of the type of $C$. elata along the 550 lakeshore (but also the Phragmites communis belt near the lakeshore and ponds) can be flooded 551 in spring, and the least possible vegetation of the type of S. nigricans (and neighboring Molinia coearulea vegetation) is reached by lake water (Buttler et al., 1995). These findings are important because they provide a threshold for flooding regime by the lake in the context of optimization of lake level regulation under various stakeholders needs. An inadequate water management would affect soil sustainability with a loss of $\mathrm{C}$ from the highly organic soils if they would be less flooded. In the opposite, dryer soils would also trigger shrub encroachments and lead to a loss of the most valuable habitats in connection with the lake, which are crucial for many organisms, as for example for fish and bird reproduction. Finally, a general flooding would suppress in the upland wetlands some plant and animal species of high naturalistic importance such as orchids or tree frog.

\section{Acknowledgements}

We thank Sylvain Lanz, Emmanuel Carino, Mitsuo Wada, Gil Fontannaz and Yannic Bernard for their contributions to the sampling in the field and some laboratory work. We are very grateful to Christian Clerc from the Association de la Grande Cariçaie, Champittet, for guidance and help for site selection. We also thank the China Scholarship Council for the PhD grant attributed to Wenjuan Feng, the National Key Research and Development Program of China (2018YFE0206400) and the EPFL for financial support.

Conflict of interest: The authors declare that they have no conflict of interest.

\section{References}


573 Agren, G.I., 2008. Stoichiometry and Nutrition of Plant Growth in Natural Communities.

$574 \quad$ Annual Review of Ecology Evolution and Systematics 39, 153-170.

575 Aldous, A.R., 2002. Nitrogen translocation in Sphagnum mosses: effects of atmospheric 576 nitrogen deposition. New Phytologist 156, 241-253.

577 Bai, J.H., Ouyang, H., Deng, W., Zhu, Y.M., Zhang, X.L., Wang, Q.G., 2005. Spatial 578 distribution characteristics of organic matter and total nitrogen of marsh soils in river 579 marginal wetlands. Geoderma 124, 181-192.

580 Baldwin, D.S., Mitchell, A.M., 2000. The effects of drying and re-flooding on the sediment and 581 soil nutrient dynamics of lowland river-floodplain systems: A synthesis. Regulated Rivers$582 \quad$ Research \& Management 16, 457-467.

583 Bayley, S.E., Zoltek, J.J., Hermann, A.J., Dolan, T.J., Tortora, L., 1985. Experimental 584 manipulation of nutrients and water in a freshwater marsh: effects on biomass, 585 decomposition, and nutrient accumulation. Limnology and Oceanography 30, 500-512.

586 Bedford, B.L., Walbridge, M.R., Aldous, A., 1999. Patterns in nutrient availability and plant 587 diversity of temperate North American wetlands. Ecology 80, 2151-2169.

588 Bell, C., Carrillo, Y., Boot, C.M., Rocca, J.D., Pendall, E., Wallenstein, M.D., 2014. 589 Rhizosphere stoichiometry: are C:N:P ratios of plants, soils, and enzymes conserved at the 590 plant species-level? New Phytologist 201, 505-517.

591 Bever, J.D., Dickie, I.A., Facelli, E., Facelli, J.M., Klironomos, J., Moora, M., Rillig, M.C., 592 Stock, W.D., Tibbett, M., Zobel, M., 2010. Rooting theories of plant community ecology in 593 microbial interactions. Trends in Ecology \& Evolution 25, 468-478.

594 Blodau, C., Moore, T.R., 2003. Experimental response of peatland carbon dynamics to a water 595 table fluctuation. Aquatic Sciences 65, 47-62. 
596 Bragazza, L., Bardgett, R.D., Mitchell, E.A.D., Buttler, A., 2015. Linking soil microbial 597 communities to vascular plant abundance along a climate gradient. New Phytologist 205, 598 $1175-1182$.

599 Bragazza, L., Parisod, J., Buttler, A., Bardgett, R.D., 2013. Biogeochemical plant-soil microbe 600 feedback in response to climate warming in peatlands. Nature Climate Change 3, 273-277. 601 Brookes, P.C., Landman, A., Pruden, G., Jenkinson, D.S., 1985. Chloroform Fumigation and 602 the Release of Soil-Nitrogen - a Rapid Direct Extraction Method to Measure Microbial 603 Biomass Nitrogen in Soil. Soil Biology \& Biochemistry 17, 837-842.

604 Brookes, P.C., Powlson, D.S., Jenkinson, D.S., 1982. Measurement of Microbial Biomass 605 Phosphorus in Soil. Soil Biology \& Biochemistry 14, 319-329.

606 Bueche, M., Buttler, A., Cornali, Ph., Perrochet, P., 1994. Effects of water level regulation of 607 lake Neuchâtel (Switzerland) on the shore wetlands: mathematical modelling of 608 groundwater-lakewater interactions. Proceedings of the International Symposium 609 "Conservation and Management of Fens", 6th-10th June 1994, Poland, International Peat 610 Society - Agricultural University Warsaw, pp. 201-212.

611 Buttler, A. Quelques aspects climatiques dans les marais non boisés de la rive sud du lac de 612 Neuchâtel (Suisse). Bulletin de la Société Neuchâteloise des Sciences Naturelles 113, 217613230.

614 Buttler, A., 1987. Etude écosystémique des marais non boisés de la rive sud du lac de Neuchâtel 615 (Suisse): phytosociologie, pédologie, hydrodynamique et hydrochimie, production végétale, 616 cycles biogéochimiques et influence du fauchage sur la végétation. Thèse de doctorat, 617 Université de Neuchâtel (Suisse), pp. 284.

618 Buttler, A., 1992. Hydrochimie des nappes des prairies humides de la rive sud du lac de 619 Neuchâtel. Bulletin d'Écologie 23, 35-47.

620 Buttler, A., Bueche, M., Cornali, Ph., Gobat, J.M., 1985. Historischer und ökologischer 
622 Buttler, A., Cornali, P., Bueche, M., 1995. Etude des effets de la régulation des lacs 623 subjurassiens sur la végétation et le milieu. Rapport Université de Neuchâtel, sur mandat de l'Office fédéral de l'environnement, des forêts et du paysage (OFEFP), 154, + annexes.

625 Buttler, A., G. Mulhauser, G., 1994. The result of a century of hydrological control - the 626 fenlands of La Grande Cariçaie, in: Gruenig, A. (ed.). Mires and Man. Mire Conservation in a Densely Populated Country - the Swiss Experience. Excursion Guide and Symposium Proceedings of the 5th Field Symposium of the International Mire Conservation Group (IMCG) to Switzerland 1992. Birmensdorf, Swiss Federal Institute for Forest, Snow and Landscape Research, 173-180.

Buttler, A., Gallandat, J.D., 1989. Phytosociologie des prairies humides de la rive sud du lac de Neuchâtel (Suisse) et modèle de succession autogène. Phytocoenologia 18, 129-158.

Buttler, A., Gobat, J.M., 1991. Les sols hydromorphes des prairies humides de la rive sud du lac de Neuchâtel (Suisse). Bulletin d'Écologie 22, 405-418.

Cui, Y.X., Fang, L.C., Guo, X.B., Wang, X., Zhang, Y.J., Li, P.F., Zhang, X.C., 2018. Ecoenzymatic stoichiometry and microbial nutrient limitation in rhizosphere soil in the arid area of the northern Loess Plateau, China. Soil Biology \& Biochemistry 116, 11-21.

Dawson, T.P., Berry, P.M., Kampa, E., 2003. Climate change impacts on freshwater wetland habitats. Journal for Nature Conservation 11, 25-30.

640 De Graaff, M.A., Classen, A.T., Castro, H.F., Schadt, C.W., 2010. Labile soil carbon inputs 641 mediate the soil microbial community composition and plant residue decomposition rates. $642 \quad$ New Phytologist 188, 1055-1064.

643 De Neiff, A.P., Neiff, J.J., Casco, S.L., 2006. Leaf litter decomposition in three wetland types of the Paraná River floodplain. Wetlands 26, 558-566. 
645 Demars, B.O.L., Edwards, A.C., 2007. Tissue nutrient concentrations in freshwater aquatic 646 macrophytes: high inter-taxon differences and low phenotypic response to nutrient supply. 647 Freshwater Biology 52, 2073-2086.

648 Dykyjová, D., Úlehlová, B., 1978. Structure and chemistry of the fishpond bottom, Pond 649 Littoral Ecosystems. Springer, Berlin, pp. 141-156.

650 Elser, J.J., Fagan, W.F., Kerkhoff, A.J., Swenson, N.G., Enquist, B.J., 2010. Biological 651 stoichiometry of plant production: metabolism, scaling and ecological response to global 652 change. New Phytologist 186, 593-608.

653 Freeman, C., Ostle, N.J., Fenner, N., Kang, H., 2004. A regulatory role for phenol oxidase 654 during decomposition in peatlands. Soil Biology \& Biochemistry 36, 1663-1667.

655 Fu, X.H., Li, F., Zhu, L.L., Xie, Y.H., Hu, C., Chen, X.S., Deng, Z.M., 2018. Change in 656 ecological stoichiometry of Carex brevicuspis in response to seasonal dynamics and 657 elevation in Dongting Lake, China. Nordic Journal of Botany 36, e01821.

658 Gibbs, J.P., 2000. Wetland loss and biodiversity conservation. Conservation Biology 14, 314659317.

660 Gil-Sotres, F., Trasar-Cepeda, C., Leirós, M., Seoane, S., 2005. Different approaches to 661 evaluating soil quality using biochemical properties. Soil Biology and Biochemistry 37, 877662 887.

663 Güsewell, S., Koerselman, W., 2002. Variation in nitrogen and phosphorus concentrations of 664 wetland plants. Perspectives in Plant Ecology, Evolution and Systematics 5, 37-61.

665 Heuck, C., Weig, A., Spohn, M., 2015. Soil microbial biomass C:N:P stoichiometry and 666 microbial use of organic phosphorus. Soil Biology \& Biochemistry 85, 119-129.

667 Hingray, B., Mouhous, N., Mezghani, A., Bogner, K., Schaefli, B., Musy, A., 2007. Accounting 668 for global-mean warming and scaling uncertainties in climate change impact studies: 669 application to a regulated lake system. Hydrology and Earth System Sciences 11, 1207-1226. 
670 Hobbie, S.E., Reich, P.B., Oleksyn, J., Ogdahl, M., Zytkowiak, R., Hale, C., Karolewski, P., 671 2006. Tree species effects on decomposition and forest floor dynamics in a common garden. $672 \quad$ Ecology 87, 2288-2297.

673 Hopkinson, C.S., 1992. A comparison of ecosystem dynamics in freshwater wetlands. Estuaries $674 \quad 15,549-562$.

675 Hu, M.J., Penuelas, J., Sardans, J., Sun, Z.G., Wilson, B., Huang, J.F., Zhu, Q.L., Tong, C., 676 2018. Stoichiometry patterns of plant organ N and P in coastal herbaceous wetlands along 677 the East China Sea: implications for biogeochemical niche. Plant and Soil 431, 273-288.

678 Kardol, P., Cregger, M.A., Campany, C.E., Classen, A.T., 2010. Soil ecosystem functioning 679 under climate change: plant species and community effects. Ecology 91, 767-781.

680 Kazakou, E., Garnier, E., Navas, M.L., Roumet, C., Collin, C., Laurent, G., 2007. Components 681 of nutrient residence time and the leaf economics spectrum in species from Mediterranean 682 old-fields differing in successional status. Functional Ecology 21, 235-245.

683 Kim, Y., Ullah, S., Moore, T.R., Roulet, N.T., 2014. Dissolved organic carbon and total 684 dissolved nitrogen production by boreal soils and litter: the role of flooding, oxygen 685 concentration, and temperature. Biogeochemistry 118, 35-48.

686 Lai, X., Shankman, D., Huber, C., Yesou, H., Huang, Q., Jiang, J., 2014. Sand mining and 687 increasing Poyang Lake's discharge ability: A reassessment of causes for lake decline in 688 China. Journal of Hydrology 519, 1698-1706.

689 Li, F., Gao, H., Zhu, L.L., Xie, Y.H., Yang, G.S., Hu, C., Chen, X.S., Deng, Z.M., 2017. Foliar 690 nitrogen and phosphorus stoichiometry of three wetland plants distributed along an elevation 691 gradient in Dongting Lake, China. Scientific Reports 7, 2820.

692 Li, F., Hu, C., Xie, Y.H., Liu, W.Z., Chen, X.S., Deng, Z.M., Hou, Z.Y., 2018. Influence of 693 Differ P Enrichment Frequency on Plant Growth and Plant C:N:P in a P-Limited Subtropical $694 \quad$ Lake Wetland, China. Frontiers in Plant Science 9, 1608. 
695

696

Liu, F.D., Liu, Y.H., Wang, G.M., Song, Y., Liu, Q., Li, D.S., Mao, P.L., Zhang, H., 2015. Seasonal Variations of C: N: P Stoichiometry and Their Trade-Offs in Different Organs of Suaeda salsa in Coastal Wetland of Yellow River Delta, China. Plos One 10, e0138169.

Manzoni, S., Taylor, P., Richter, A., Porporato, A., Ågren, G.I., 2012. Environmental and stoichiometric controls on microbial carbon-use efficiency in soils. New Phytologist 196, 79-91.

Mao, R., Chen, H.M., Zhang, X.H., Shi, F.X., Song, C.C., 2016. Effects of P addition on plant $\mathrm{C}: \mathrm{N}: \mathrm{P}$ stoichiometry in an $\mathrm{N}$-limited temperate wetland of Northeast China. Science of the Total Environment 559, 1-6.

Neckles, H.A., Neill, C., 1994. Hydrologic Control of Litter Decomposition in Seasonally Flooded Prairie Marshes. Hydrobiologia 286, 155-165.

Olsen, S., Cole, C., Watanabe, F., Dean, L., 1954. Estimation of available phosphorus in soils by extraction with sodium bicarbonate. USDA Circular Nr 939, US Gov. Print. Office, Washington, D.C.

Olson, J.S., 1963. Energy storage and the balance of producers and decomposers in ecological systems. Ecology 44, 322-331.

Qiu, S., McComb, A.J., 1995. Planktonic and microbial contributions to phosphorus release from fresh and air-dried sediments. Marine and Freshwater Research 46, 1039-1045.

Pinheiro, J., Bates, D., DebRoy, S., Sarkar, D., 2020. nlme: Linear and Nonlinear Mixed Effects Models. R package version 3.1-147, https://CRAN.R-project.org/package=nlme.Ramsar, 2013. The Ramsar Manual. 6th ed. Ramsar Convention Secretariat, Switzerland, pp. 110.

Richardson, A.E., Barea, J.-M., McNeill, A.M., Prigent-Combaret, C., 2009. Acquisition of phosphorus and nitrogen in the rhizosphere and plant growth promotion by microorganisms. Plant and Soil 321, 305-339. 
719 Rokosch, A.E., Bouchard, V., Fennessy, S., Dick, R., 2009. The use of soil parameters as indicators of quality in forested depressional wetlands. Wetlands 29, 666-677.

721 Sardans, J., Bartrons, M., Margalef, O., Gargallo-Garriga, A., Janssens, I.A., Ciais, P., 722 Obersteiner, M., Sigurdsson, B.D., Chen, H.Y.H., Peñuelas, J., 2017. Plant invasion is 723 associated with higher plant-soil nutrient concentrations in nutrient-poor environments. $724 \quad$ Global Change Biology 23, 1282-1291.

725 Sardans, J., Peñuelas, J., 2012. The Role of Plants in the Effects of Global Change on Nutrient 726 Availability and Stoichiometry in the Plant-Soil System. Plant Physiology 160, 1741-1761.

727 728 729 730

731

732

Sarneel, J.M., Hefting, M.M., Kowalchuk, G.A., Nilsson, C., Van der Velden, M., Visser, E.J., Voesenek, L.A., Jansson, R., 2019. Alternative transient states and slow plant community responses after changed flooding regimes. Global Change Biology 25, 1358-1367.

Shrestha, J., Niklaus, P.A., Pasquale, N., Huber, B., Barnard, R.L., Frossard, E., Schleppi, P., Tockner, K., Luster, J., 2014. Flood pulses control soil nitrogen cycling in a dynamic river floodplain. Geoderma 228, 14-24.

Sinsabaugh, R.L., Hill, B.H., Shah, J.J.F., 2009. Ecoenzymatic stoichiometry of microbial organic nutrient acquisition in soil and sediment. Nature 462, 795-798.

Sinsabaugh, R.L., Lauber, C.L., Weintraub, M.N., Ahmed, B., Allison, S.D., Crenshaw, C., Contosta, A.R., Cusack, D., Frey, S., Gallo, M.E., Gartner, T.B., Hobbie, S.E., Holland, K., Keeler, B.L., Powers, J.S., Stursova, M., Takacs-Vesbach, C., Waldrop, M.P., Wallenstein, M.D., Zak, D.R., Zeglin, L.H., 2008. Stoichiometry of soil enzyme activity at global scale. Ecology Letters 11, 1252-1264.

Swanson, W., De Jager, N.R., Strauss, E., Thomsen, M., 2017. Effects of flood inundation and invasion by Phalaris arundinacea on nitrogen cycling in an Upper Mississippi River floodplain forest. Ecohydrology 10, e1877. 
743 Wang, M., Moore, T.R., 2014. Carbon, Nitrogen, Phosphorus, and Potassium Stoichiometry in 744 an Ombrotrophic Peatland Reflects Plant Functional Type. Ecosystems 17, 673-684.

745 Wang, W.Q., Sardans, J., Wang, C., Zeng, C.S., Tong, C., Bartrons, M., Asensio, D., Penuelas,

746

747 J., 2018. Shifts in plant and soil C, N and P accumulation and C:N:P stoichiometry associated with flooding intensity in subtropical estuarine wetlands in China. Estuarine Coastal and Shelf Science 215, 172-184.

Wang, W.Q., Wang, C., Sardans, J., Tong, C., Jia, R.X., Zeng, C.S., Penuelas, J., 2015a. Flood regime affects soil stoichiometry and the distribution of the invasive plants in subtropical estuarine wetlands in China. Catena 128, 144-154.

Wang, W.Q., Wang, C., Sardans, J., Zeng, C.S., Tong, C., Peñuelas, J., 2015b. Plant invasive success associated with higher $\mathrm{N}$-use efficiency and stoichiometric shifts in the soil-plant system in the Minjiang River tidal estuarine wetlands of China. Wetlands ecology and management 23, 865-880.

Wang, X.L., Xu, L.G., Wan, R.G., Chen, Y.W., 2016. Seasonal variations of soil microbial biomass within two typical wetland areas along the vegetation gradient of Poyang Lake, China. Catena 137, 483-493.

Wilson, J.S., Baldwin, D.S., Rees, G.N., Wilson, B.P., 2011. The Effects of Short-Term Inundation on Carbon Dynamics, Microbial Community Structure and Microbial Activity in Floodplain Soil. River Research and Applications 27, 213-225.

Wolf, K.L., Noe, G.B., Ahn, C., 2013. Hydrologic Connectivity to Streams Increases Nitrogen and Phosphorus Inputs and Cycling in Soils of Created and Natural Floodplain Wetlands. Journal of Environmental Quality 42, 1245-1255.

Wright, I.J., Reich, P.B., Westoby, M., Ackerly, D.D., Baruch, Z., Bongers, F., CavenderBares, J., Chapin, T., Cornelissen, J.H., Diemer, M., 2004. The worldwide leaf economics spectrum. Nature 428, 821-827. 
768 Xu, S.Q., Liu, X., Li, X.J., Tian, C.J., 2019. Soil organic carbon changes following wetland 769 cultivation: A global meta-analysis. Geoderma 347, 49-58.

770 Zechmeister-Boltenstern, S., Keiblinger, K.M., Mooshammer, M., Peñuelas, J., Richter, A.,

771 Sardans, J., Wanek, W., 2015. The application of ecological stoichiometry to plant772 microbial-soil organic matter transformations. Ecological Monographs 85, 133-155. 
775

776 Table 1 Effects of vegetation type, growing season, and their interaction on plant and moss

777 parameters. $F$-values and associated $P$-values (* for $P<0.05$, ** for $P<0.01$ and *** for $P<$

778 0.001) are indicated (see values of variables in Supplementary Table S2).

779

\begin{tabular}{|c|c|c|c|c|c|c|}
\hline & \multicolumn{2}{|c|}{ Vegetation type } & \multicolumn{2}{|c|}{ Growing season } & \multicolumn{2}{|c|}{$\mathrm{VT} \times \mathrm{GS}$} \\
\hline Aboveground biomass (AGB) & 3.5 & & 189.0 & $* * *$ & 13.4 & $* *$ \\
\hline $\mathrm{C}$ content of $\mathrm{AGB}$ & 3.5 & & 2.4 & & 0.0 & \\
\hline N content of AGB & 17.1 & $* *$ & 0.7 & & 4.5 & $*$ \\
\hline P content of AGB & 111.7 & $* * *$ & 119.9 & $* * *$ & 27.4 & $* * *$ \\
\hline Litter (L) & 14.6 & $* *$ & 7.4 & $*$ & 1.9 & \\
\hline C content of $\mathrm{L}$ & 10.0 & $*$ & 18.0 & $* *$ & 0.4 & \\
\hline $\mathrm{N}$ content of $\mathrm{L}$ & 1.2 & & 9.5 & $*$ & 0.2 & \\
\hline P content of $L$ & 4.5 & & 4.9 & & 2.0 & \\
\hline Moss biomass (MB) & 3.2 & & 2.9 & & 7.8 & $*$ \\
\hline $\mathrm{C}$ content of $\mathrm{MB}$ & 3.0 & & 0.6 & & 0.6 & \\
\hline $\mathrm{N}$ content of MB & 6.5 & $*$ & 0.8 & & 1.1 & \\
\hline $\mathrm{P}$ content of MB & 13.2 & $* *$ & 4.7 & & 2.1 & \\
\hline Belowground biomass (BGB) & 10.8 & $* *$ & 4.4 & & 0.7 & \\
\hline $\mathrm{C}$ content of BGB & 7.9 & $*$ & 4.9 & & 0.1 & \\
\hline $\mathrm{N}$ content of $\mathrm{BGB}$ & 1.9 & & 12.1 & ** & 3.0 & \\
\hline $\mathrm{P}$ content of BGB & 0.4 & & 32.9 & $* * *$ & 1.3 & \\
\hline
\end{tabular}

780 
782 Table 2 Synthesis of the effects of vegetation gradient and growing season on plant and moss

783 parameters. Vegetation gradient is considered from lakeshore to upland (i.e. from C. elata to $S$.

784 nigricans community) while growing season is considered from beginning to peak of growing

785 season. $\searrow$ indicates a significant decrease of the value $(\triangleleft \rightarrow$ indicates a significant decrease only

786 between two vegetation types), $\nearrow$ indicates a significant increase of the value and the absence

787 of arrow indicates the absence of a significant effect (see Table 1).

788

\begin{tabular}{lcc}
\hline & $\begin{array}{c}\text { Vegetation } \\
\text { gradient }\end{array}$ & $\begin{array}{c}\text { Growing } \\
\text { season }\end{array}$ \\
\hline A boveground biomass (AGB) & & $\nearrow$ \\
$\mathrm{C}$ content of AGB & $\searrow$ & \\
$\mathrm{N}$ content of AGB & $\searrow$ & $\searrow$ \\
$\mathrm{P}$ content of AGB & $\searrow \rightarrow$ & $\searrow$ \\
Litter (L) & $\searrow$ & $\nearrow$ \\
$\mathrm{C}$ content of L & & $\searrow$ \\
$\mathrm{N}$ content of L & & \\
P content of L & & \\
Moss biomass (MB) & & \\
C content of MB & $\searrow$ & \\
N content of MB & $\searrow$ & \\
P content of MB & $\searrow$ & \\
Belowground biomass (BGB) & $\searrow$ & \\
C content of BGB & $\searrow$ \\
N content of BGB & & $\searrow$ \\
P content of BGB & & \\
\hline
\end{tabular}

789 
Table 3 Effects of soil layer, vegetation type, growing season, and their interaction on soil physico-chemical, microbial and enzymatic parameters.

\begin{tabular}{|c|c|c|c|c|c|c|c|c|c|c|c|c|c|c|}
\hline \multirow[b]{2}{*}{ Bulk density (BD) } & \multicolumn{2}{|c|}{ Soil layer } & \multicolumn{2}{|c|}{ Vegetation type } & \multicolumn{2}{|c|}{ Growing season } & \multicolumn{2}{|c|}{$\mathrm{SL} \times \mathrm{VT}$} & \multicolumn{2}{|c|}{$\mathrm{SL} \times \mathrm{GS}$} & \multicolumn{2}{|c|}{$\mathrm{VT} \times \mathrm{GS}$} & \multicolumn{2}{|c|}{$\mathrm{SL} \times \mathrm{VT} \times \mathrm{GS}$} \\
\hline & 243.2 & **** & 21.5 & $* *$ & 1.9 & & 6.2 & **** & 0.3 & & 1.7 & & 0.6 & *** \\
\hline Soil water content (SWC) & 171.2 & $* * *$ & 15.4 & $* *$ & 3.7 & & 2.6 & $*$ & 0.9 & & 3.1 & & 0.1 & \\
\hline Soil pH & 139.8 & $* * *$ & 18.4 & $* *$ & 145.3 & $* * *$ & 1.0 & & 0.5 & & 2.8 & & 1.3 & \\
\hline Soil organic matter (LOI) & 423.1 & $* * *$ & 23.4 & $* *$ & 0.6 & & 16.1 & $* * *$ & 0.2 & & 1.7 & & 0.2 & \\
\hline Soil organic C (TOC) & 160.8 & $* * *$ & 15.7 & $* *$ & 0.9 & & 7.0 & $* * *$ & 0.3 & & 1.2 & & 0.4 & \\
\hline Soil N (TN) & 422.8 & $* * *$ & 30.0 & $* * *$ & 0.3 & & 11.2 & $* * *$ & 0.7 & & 1.9 & & 0.6 & \\
\hline Soil P (TP) & 240.3 & $* * *$ & 13.5 & $* *$ & 1.3 & & 18.4 & $* * *$ & 0.2 & & 0.3 & & 0.6 & \\
\hline Soil available C (DOC) & 402.0 & $* * *$ & 10.7 & $* *$ & 0.0 & & 10.6 & $* * *$ & 1.8 & & 4.8 & $*$ & 0.5 & \\
\hline Soil available $\mathrm{N}(\mathrm{DN})$ & 139.8 & $* * *$ & 2.7 & & 138.3 & $* * *$ & 5.2 & $* *$ & 3.9 & $*$ & 3.1 & & 1.8 & \\
\hline Soil available $\mathrm{P}(\mathrm{DP})$ & 372.6 & $* * *$ & 19.2 & $* *$ & 2.0 & & 6.5 & $* * *$ & 0.2 & & 2.9 & & 1.1 & \\
\hline Ammonium (N-NH4) & 193.5 & $* * *$ & 7.2 & $*$ & 0.6 & & 4.6 & $* *$ & 6.0 & $* *$ & 0.0 & & 0.5 & \\
\hline Nitrate $(\mathrm{N}-\mathrm{NO} 3)$ & 41.4 & $* * *$ & 17.7 & $* *$ & 40.3 & $* * *$ & 2.6 & & 2.1 & & 3.2 & $*$ & 0.5 & \\
\hline Microbial biomass $\mathrm{C}(\mathrm{MBC})$ & 467.0 & $* * *$ & 6.0 & * & 4.1 & & 14.6 & $* * *$ & 0.9 & & 2.9 & & 1.9 & \\
\hline Microbial biomass $\mathrm{N}(\mathrm{MBN})$ & 804.2 & $* * *$ & 11.1 & $* *$ & 4.1 & & 11.5 & $* * *$ & 0.5 & & 1.0 & & 0.6 & \\
\hline Microbial biomass $\mathrm{P}(\mathrm{MBP})$ & 525.9 & $* * *$ & 47.4 & $* * *$ & 0.3 & & 22.2 & $* * *$ & 0.1 & & 0.7 & & 0.6 & \\
\hline ß-glucosidase (BG)) & 206.9 & $* * *$ & 67.5 & $* * *$ & 13.6 & $* *$ & 4.4 & $* *$ & 2.7 & & 8.1 & $* *$ & 4.1 & $* *$ \\
\hline Leucine aminopeptidase (LAP) & 642.1 & $* * *$ & 16.0 & $* * *$ & 20.5 & $* * *$ & 0.6 & & 19.2 & $* * *$ & 18.2 & $* * *$ & 0.7 & \\
\hline$\beta-1,4-\mathrm{N}$-acetylglucosaminidase (NAG) & 156.0 & $* * *$ & 54.3 & $* * *$ & 29.4 & $* * *$ & 12.0 & $* * *$ & 2.0 & & 0.7 & & 10.0 & $* * *$ \\
\hline Phosphatase (PHO) & 169.7 & $* * *$ & 29.9 & $* * *$ & 21.8 & $* * *$ & 7.2 & $* * *$ & 21.6 & $* * *$ & 6.9 & $* *$ & 4.5 & ** \\
\hline
\end{tabular}


797 Table 4 Synthesis of the effects of soil depth increase, vegetation gradient and growing season,

798 on soil physico-chemical, microbial and enzymatic parameters. Soil depth increase is

799 considered from surface organic to lower mineral layer, vegetation gradient from lakeshore to

800 upland (i.e. from C. elata to S. nigricans community), while growing season is considered from

801 beginning to peak of growing season. $\searrow$ indicates a significant decrease of the value $(\searrow \rightarrow$

802 indicates a significant decrease only between two vegetation types), $\nearrow$ indicates a significant

803 increase of the value and the absence of arrow indicates the absence of a significant effect (see

804 Table 3).

\begin{tabular}{lccc}
\hline & $\begin{array}{c}\text { Increasing } \\
\text { soil depth }\end{array}$ & $\begin{array}{c}\text { Vegetation } \\
\text { gradient }\end{array}$ & $\begin{array}{c}\text { Growing } \\
\text { season }\end{array}$ \\
\hline Soil physico-chemical parameters & & & \\
Bulk density (BD) & $\nearrow$ & $\nearrow$ & \\
Soil water content (SWC) & $\searrow$ & $\searrow$ & $\nearrow$ \\
Soil pH & $\nearrow$ & $\nearrow$ & \\
Soil organic matter (LOI) & $\searrow$ & $\searrow$ & \\
Soil organic C (TOC) & $\searrow$ & $\searrow$ & \\
Soil N (TN) & $\searrow$ & $\searrow$ & \\
Soil P (TP) & $\searrow$ & $\searrow$ \\
Soil available C (DOC) & $\searrow$ & $\searrow$ & \\
Soil available N (DN) & $\searrow$ & \\
Soil available P (DP) & $\searrow$ & \\
Ammonium (N-NH4) & $\searrow$ & $\searrow$ \\
Nitrate (N-NO3) & $\searrow$ & \\
Microbial parameters & $\searrow$ & $\searrow$ & \\
Microbial biomass C (MBC) & $\searrow$ & \\
Microbial biomass N (MBN) & $\searrow$ & \\
Microbial biomass P (MBP) & $\searrow$ & \\
Enzymatic parameters & $\searrow$ & \\
B-glucosidase (BG) & $\searrow$ & \\
Leucine aminopeptidase (LAP) & $\searrow$ & \\
B -1, 4-N-acetylglucosaminidase (NAG) & $\searrow$ & \\
Phosphatase (PHO) & $\searrow$ & \\
\hline
\end{tabular}


808 Fig. 1 Aboveground plant biomass (a), moss biomass (b), $\mathrm{N}$ content in aboveground plant

809 biomass (c) and P content in aboveground plant biomass (d) according to the vegetation type $810 \times$ growing season interaction (Table 1). Each bar represents the mean value $\pm S E ; n=4$. For 811 (a), (b) and (c), different letters denote significant differences among plant communities 812 according to the selected growing season period with $a>b>c$. For (d), stars indicate significant 813 differences between the beginning and the peak of growing season according to the selected 814 plant community with $*$ for $P<0.05$, ** for $P<0.01$ and $n s$ for $P>0.05$. CE $=$ C. elata, $\mathrm{CP}=$ C. panicea, $\mathrm{SN}=S$. nigricans, $\mathrm{GS}=$ growing season.

816

817 Fig. 2 Soil total P content (a), available P content (b), microbial biomass C (c) and leucine

818 aminopeptidase activity (d) according to the soil layer $\times$ vegetation type interaction (Table 3 ).

819 Each bar represents the mean value $\pm S E ; n=8$. Different letters denote significant differences 820 among plant communities according to the selected soil layer with a $>\mathrm{b}>\mathrm{c} . \mathrm{CE}=C$. elata, $\mathrm{CP}$ $821=$ C. panicea, $\mathrm{SN}=$ S. nigricans. $\mathrm{LAP}=$ leucine aminopeptidase.

823 Fig. 3 Soil available C (a) and nitrate (b) contents according to the vegetation type $\times$ growing 824 season interaction (Table 3). Each bar represents the mean value $\pm S E ; n=12$. Different letters 825 denote significant differences among vegetation types according to the selected growing season 826 period with $\mathrm{a}>\mathrm{b} . \mathrm{CE}=C$. elata, $\mathrm{CP}=C$. panicea, $\mathrm{SN}=S$. nigricans. 
828 Fig. 4 Soil available $N($ a) and ammonium (b) content according to the soil layer $\times$ growing 829 season interaction (Table 3). Each bar represents the mean value $\pm S E ; n=12$. Stars indicate 830 significant differences between the beginning and the peak of growing season according to the 831 selected soil layer with * for $P<0.05$, ** for $P<0.01$, *** for $P<0.001$ and $n s$ for $P>0.05$.

832 GS = growing season.

833

834 Fig. 5 Principal component analysis (PCA) illustrating the relationship between stoichiometry 835 of $\mathrm{C}, \mathrm{N}$ and $\mathrm{P}$ in the plant material (above and belowground biomass, moss and litter), in the 836 bulk soil and in its dissolved fraction, and in the microbial biomass in the organic layer at the 837 two sampling periods, April and July. Samples are labelled with sampling period (A: April, J: 838 July) and vegetation type (CE: Carex elata, CP: Carex panicea, SN: Schoenus nigricans). 839 Variables are labelled as in Tables 1-4. 
Fig. 1

842
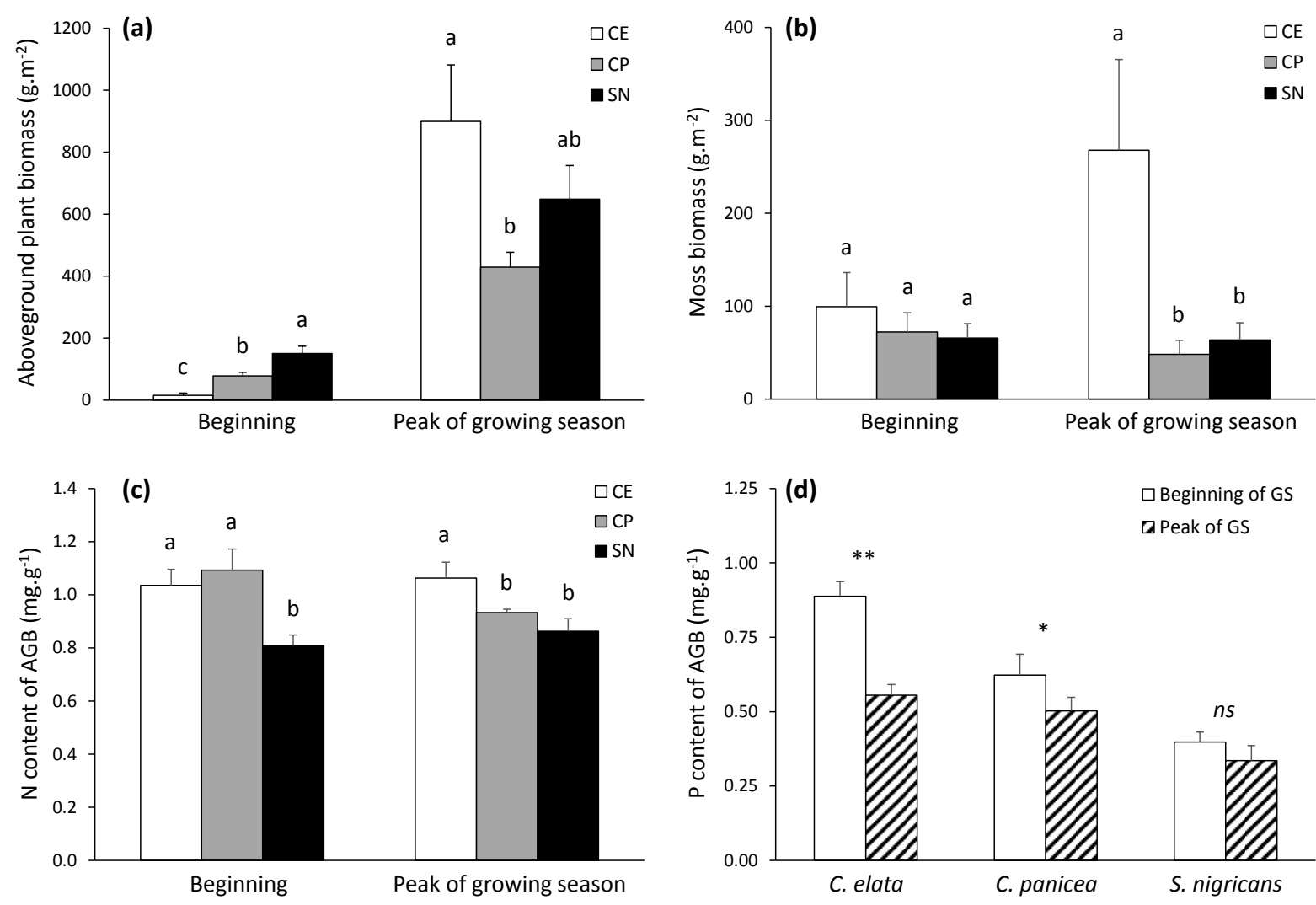
Fig. 2

846
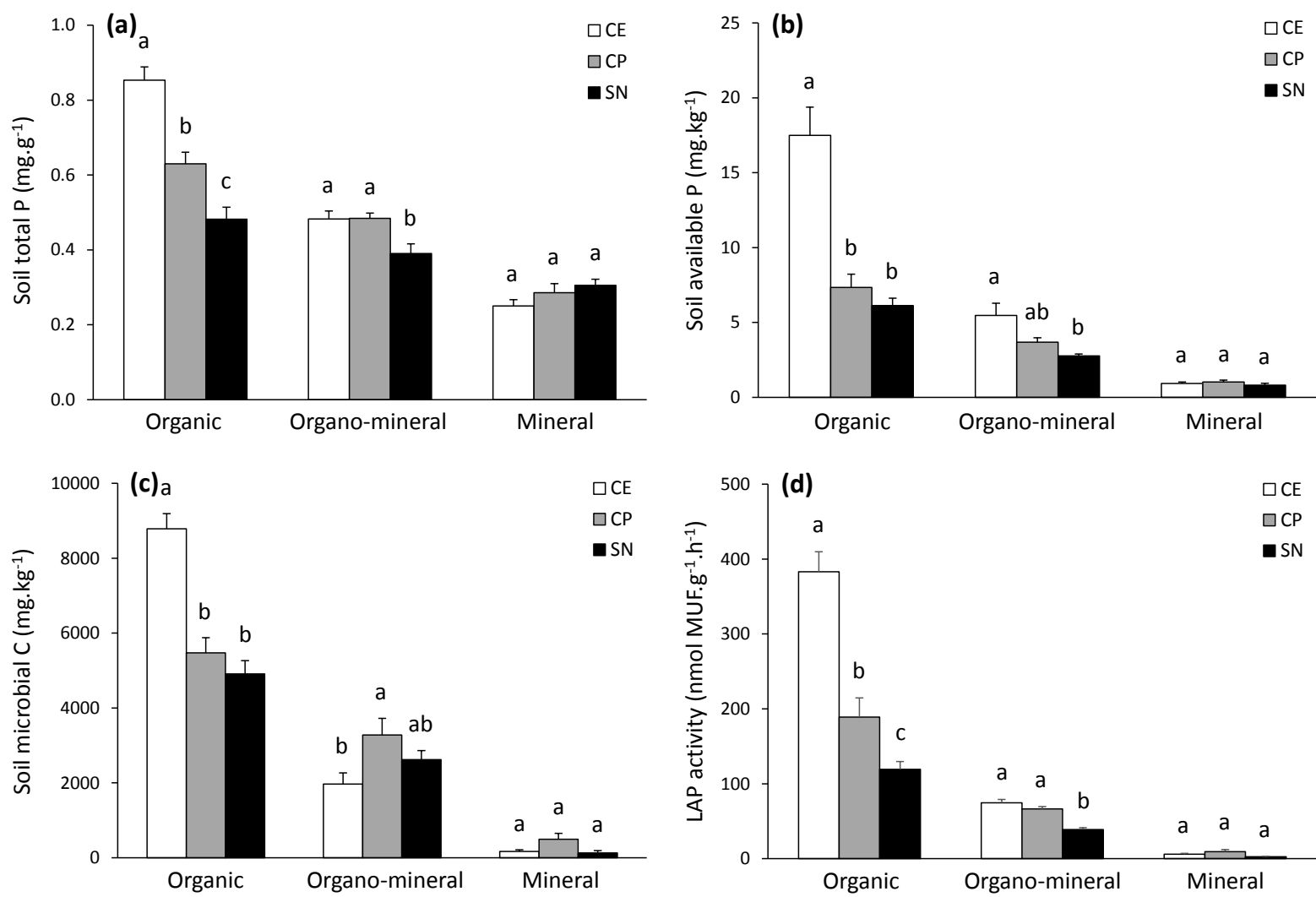
849 Fig. 3

850

851
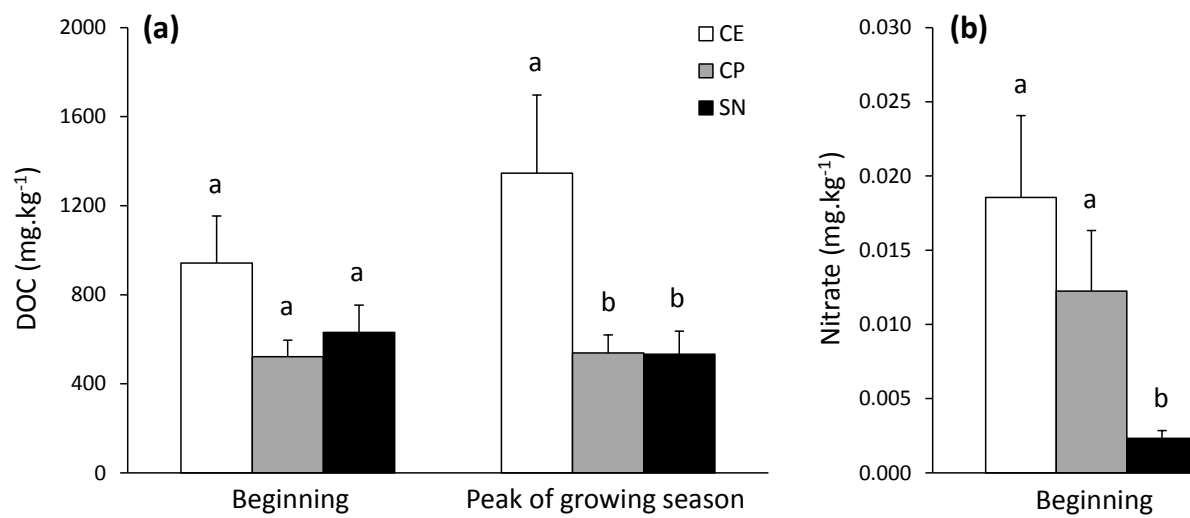

$\square C E$

$\square C P$ 
$853 \quad$ Fig. 4

854

855
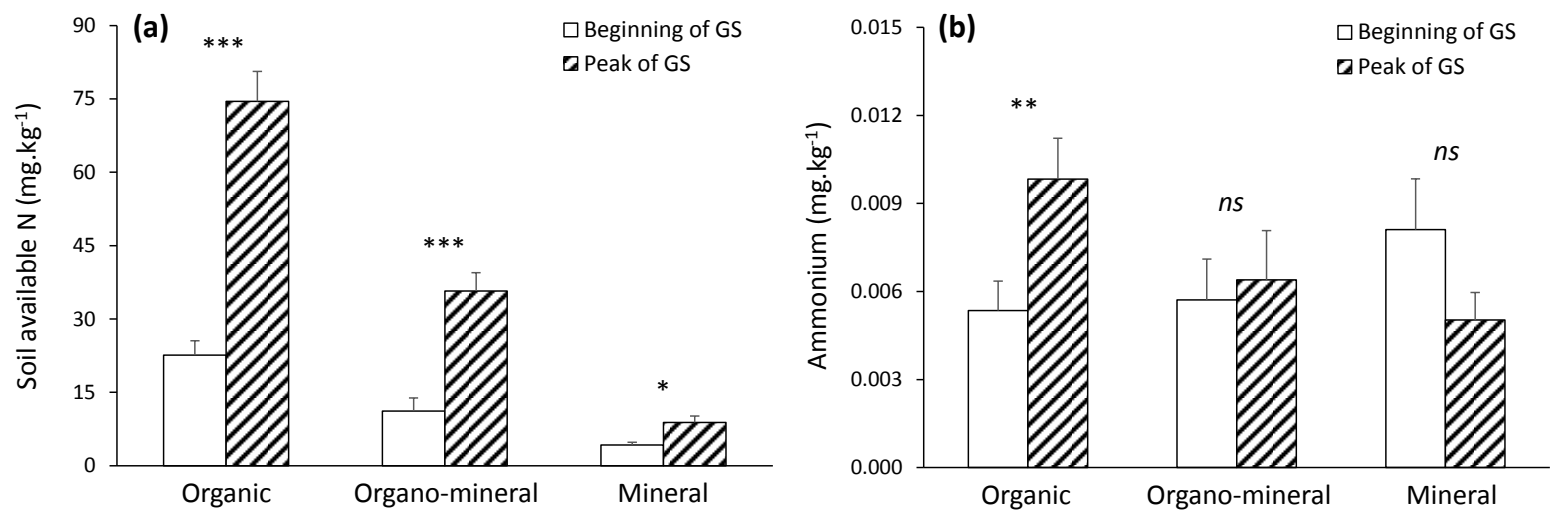

856 
Fig. 5

858

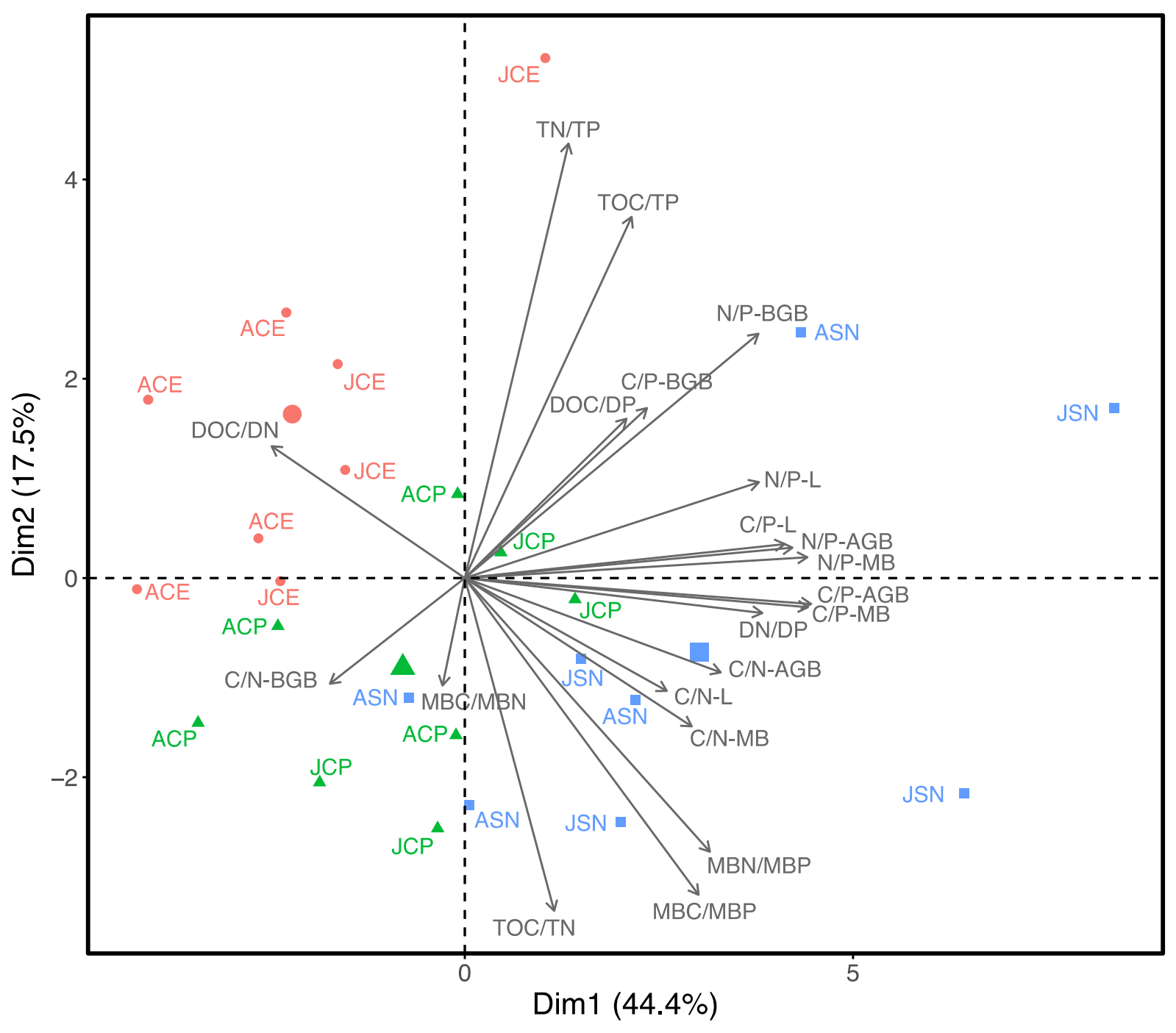

859 